\title{
INTERNATIONAL HUMAN RIGHTS LAW: Aspirations and Challenges to Global Justice and Peace
}

\author{
Doi: 10.23918/ilic2021.35 \\ Neville D'Cunha \\ Associate Professor of International Relations and Diplomacy \\ TISHK International University-Erbil, Iraq \\ neville.dcunha@tiu.edu.iq
}

\begin{abstract}
1. Introduction
1.1. Background of the Study

Human rights are moral, social, religious, and political rights that concern respect and dignity associated with personhood and a human being's identity. International human rights are those rights vital to an individual's existence. The foundation for human rights is the individual's status qua as individual within the international community and the dignity and justice owed to persons based upon that status (Freeman 2002). Justice and human dignity are concepts central to any conception of the rights of individuals.

In the beginning, individual human rights were not part of the international law paradigm. Rather, the concern of international affairs was left exclusively to the state (Oppenheim cited in Sohn \& Buergenthal 1973). With the signing of the United Nations Charter in 1945, international law structurally protected individuals qua individuals against all forms of injustice regardless of whether the abuse or injustice was committed by a foreign sovereign or the individual's own state of nationality (Donnelly 2003). International law is a crucial aspect of human rights. Governments are in a powerful position to control the freedoms of individuals or groups - freedoms that may be harder to win without international agreement and pressure. A series of human rights treaties and other instruments adopted since 1945 has developed into an influential body of international human rights. These are monitored and implemented by important international institutions including the UN Human Rights Council, UN treaty bodies, etc.

Obligations in international law are binding on countries which have agreed to abide by them. This means that when a Government has signed a treaty and Parliament has ratified it, the country has made a formal commitment and the Government must do everything the treaty requires. Some human rights - like the right not to be tortured - are absolute. These 'absolute' rights can never be interfered with in any circumstances. But most human rights are not absolute. Some are described as 'limited' which means they can be restricted in certain circumstances as specified in the relevant Articles of individual country's constitution or legal frameworks. For example, the right to liberty can be limited if a person is convicted and sentenced to prison. Other rights are described as 'qualified'. Which means they can only be restricted to protect the rights of other people or if it's in the public interest for specific reasons such as the prevention of crime. For example, the Government may restrict the right to freedom of expression if a person is encouraging racial hatred.
\end{abstract}

\subsection{Research Objectives and Questions}

This query insinuates that international human rights law provides a fulcrum from which to take a global perspective that encourages diversity of analysis rather than a parochial and nationalistic perspective that eschews others and insists on a preordained hierarchical normativity. The Questions that evolve out of our objectives are as follows:

1. Does International Human Rights Law perspective on human rights offer new perspectives on the traditional themes and concerns that have organized the legal and moral struggle to promote the recognition and enforcement of human rights?

2. Does International Human Rights Law offer new perspectives on the recent trend toward emergence of new powers and the likely impact of such developments on the 
human rights of vulnerable individuals and peoples within states considering the constantly changing dynamics between hegemonic and new powers?

3. Does International Human Rights Law is prepared to address the key debates over (a) the status of national sovereignty in international law; (b) the proper scope and limits of state intervention in civil society; and (c) the status of international human rights in economic globalization such as reluctance of states or procedural norms for the enforcement of international human rights?

\subsection{Limitations and Significance of the Study}

Without pretending to be a human rights scholar or activist or international law scholar or analyst, I wrote this article as a scholar of international relations and diplomacy with special interest in human rights system. It is about how human rights system is extremely critical to the political and social world in which we live. What the discerning reader will find in this paper is not a comprehensive and in-depth analysis of the causes and consequences of human rights violations or technical discussion of legal strategies grounded in the International Human Rights Law adopted by governments. Rather, they will find here philosophical reflection on how International human rights law system is indispensable for reclaiming human dignity that is an integral element of human rights leading to global justice and peace. The issues discussed here are serious; they are shared by scholars and activists worldwide. Human Rights principles at stake are universal ones. If this preliminary article can raise awareness of the importance of human rights as the foundation of global justice and peace, I would consider this to be a worthy contribution.

\section{Literature Review}

\subsection{Human Rights}

The definition of "human! rights" in terms of theory and function has been broad and varied. It is an institutional requirement, describing the positive and negative duties owed by political institutions to individuals. It is a legal relationship in national and international law. Post-Cold War, human rights have been embedded in numerous conventions, institutions, and courts, at the domestic, regional, and international levels, all of which now encircle in a world of law. These are all significant developments in the law and compliance regime of human rights.

There are, nevertheless, a series of concerns about the present and future of human rights effectiveness shared by legal scholars. Even in what we might think is the clearest case torture - which is against positive, customary and jus cogens law, the evidence for a reduction, let alone elimination is thin. Some legal scholars even argue that when states sign conventions like that against torture, they are more likely to torture, or to be inventive about the forms of torture they use (Hathaway 2001-2002; Rejali 2009; Fariss 2014 cited in Hopgood 2014: 69). Pressing questions also concern how much the international human rights movement, displays a political and moral economy that mirrors inequalities within and between societies. How will changes demography and technology change human rights work? Furthermore, will security concerns clash with civil and political rights, and how will social justice demands (to food, shelter, medicine, healthcare) fare if INGOs continue to prioritize issues like torture, the death penalty, freedom of religious belief and freedom of expression? These questions are growing greatly in significance because of three deeper underlying shifts in global politics. It is here that we find the real cause of the growing ineffectiveness of human rights as a movement for social change. They are the decline of Western influence and the emergence of new powers, the politicization of human rights language, and pushback against human rights on principle, particularly in case of religious belief.

Hence, there are many challenges to universal human rights. The answer will come out differently in different places, as will the language used and arguments made. All may make use of the umbrella of 'human rights,' but they will either be used so loosely as to 
provide no solace to global advocates, or they will be used so selectively so to undermine in practice the principles of universality and indivisibility.

\subsection{International Human Rights Law}

Human rights are a matter of international law, as the rights of humans do not depend on an individual's nationality and so the protection of these rights cannot be limited to the jurisdiction of any one State. Of course, national protection of human rights is vital, and many States do specifically provide for such protection. However, as most breaches of human rights are caused by a State acting against its own citizens or against those persons in its jurisdiction, much of international human rights law operates beyond the national legal system in order to afford redress to those whose human rights are infringed and to provide an international standard by which States can be judged (Dixon \& McCorquodale 2003). Ultimately, if human rights mean anything in international law, then the traditional international law of State-based jurisdictional exclusivity must give away to a realization that the rights of humans matter more than the interests of States.

International human rights law benefits significantly from enforcement by political bodies [that are within UN system and human rights treaties]. Political bodies have devoted extraordinary efforts to promoting law on human rights and they have not avoided the demands of enforcement of - inducing compliance with - that law. Political bodies are subject to their own political laws - more 'politicized,' therefore less likely to apply human rights norms judicially and impartially. In such bodies, human rights are more susceptible to being subordinated to non-human rights considerations (Henkin, cited in Dixon \& McCorquodale 2003: 195). Developing as well as Dictatorial countries (and others particularly committed to State values) have resisted an active United Nations role in human rights monitoring.

Many United Nations organizations have some responsibility for issues that concern the protection of specific human rights such as UNESCO, WHO, and even World Bank which should consider human rights breaches when deciding on funding. The UNSC can decide on a matter which concerns human rights if it considers that a threat to international peace and security is involved. Those decisions are binding on all member States of the United Nations, as provided by Article 25 of the United Nations Charter (Dixon \& McCorquodale 2003: 200). Hence, the UN has created several procedures for protecting and promoting human rights and ascertaining where human rights violations occur. Primarily these procedures are through independent bodies established by either general or specific human rights treaties, as well as inter-governmental bodies operating directly within the UN system.

The framework of international human rights law is primarily based on States being legally obliged to protect human rights within their territory. If violation of human rights occurs then the State is responsible, however, in some instances, individuals are directly responsible for violations of human rights. This occurs in universal criminal law, for which there is usually universal jurisdiction. Crimes against international law are committed by persons, not by abstract entities, and only by punishing individuals who commit such crimes can the provisions of international law be enforced. In international human rights law, which deals with State responsibility rather than individual criminal responsibility, torture is prohibited as a criminal offence to be punished under national law; in addition, all States parties to the relevant treaties have been granted, and are obliged to exercise, jurisdiction to investigate, prosecute and punish offenders (Dixon \& McCorquodale 2003: 217-8). Thus, in human rights law too, the prohibition of torture extends to and has a direct bearing on the criminal liability of individuals.

Both economic globalization and the international legal protection of human rights are part of the process of globalization in which political, economic, social, civil, and cultural relationships are not restricted to territorial boundaries and are not solely within the control of any one state. Where the violator of human rights law is not a state or its agent but is, 
for example MNC, international human rights law finds it difficult to provide any redress to the victim. In such cases, international human rights law focuses on the responsibility of a state to adopt constitutional, legislative, judicial, administrative, and other measures to ensure that human rights within its territory are protected, no matter who the perpetrator may be (McCorquodale \& Fairbrother cited in Dixon \& McCorquodale 2003: 231-2). Therefore, international human rights law needs to develop a more flexible framework within which responsibility for human rights violations is not State - based but encompasses appropriate mechanisms to address all claims for any violation of human rights.

A danger of economic globalization is its impact on the concepts and application of human rights. The dominance of globalization's focus on certain rights (civil and political) to the virtual exclusion of other rights. But the greater danger is that the values of the international community, embodied in the international legal order and created to protect human rights, are being challenged by the values of the global economic free market. Hence, it is hoped that the international human rights law will develop to protect the victim of a violation of human rights, no matter who is the violator, what is the cause or the place of violation.

\section{Method}

The analytical approach employed in this study falls broadly under the mantle of 'realistic evaluation' (Pawson \& Tilly 1997). Realistic Evaluation is based on the works of Karl Popper who developed the notion of 'piecemeal social engineering' as a method of dealing with problems. Piecemeal social engineering was to do with introducing modest changes to address specific problems, to do with harms. Popper advocated the introduction of small-scale interventions to deal with those specific harms, to check whether they were producing their intended effects and whether, also, they were producing unwanted and unintended side effects.

Realistic Evaluation is an effective method for recognizing the importance of understanding how causal factors influence human rights and in retrospect international human rights law. The Realist understands causality in terms of underlying causal mechanisms generating regularities. Its concern is with understanding causal mechanisms and the conditions under which they are activated to produce specific outcomes. What evaluation studies produce are context, mechanism outcome configurations (CMOC). A CMOC captures the linkages between the context mechanism and outcome. There are linked questions that need to be asked about every program in order that it can be understood in realist terms. The questions relate to:

- Context: what conditions are needed for a measure to trigger mechanisms to produce particular outcome patterns?

- Mechanism: what is it about a measure which may lead it to have a particular outcome pattern in each context?

- Outcome: what are the practical effects produced by causal mechanisms being triggered in each context? and

- CMOCs: how are changes in regularity (outcomes) produced by measures introduced to modify the context and balance of mechanisms triggered.

In an evaluation study it is necessary to develop CMOC theories. The empirical part of an evaluation comprises a test of CMOC theories. The initial stage of any evaluation is concerned thus with working through some CMOC theories. These can come from various sources: social science theory, results of previous evaluations, discussions with policymakers and practitioners and above all common sense. Realistic evaluation is thus a species of theory driven evaluation specified in realist terms. 


\section{Findings}

\subsection{Context: Human Rights Challenges}

- Typically, the scholarly debate over human rights is thought to take place between two opposing camps: the universalists and the cultural relativists. The universalists build their understanding of human rights upon the liberal tradition whereby rights are accorded to the individual by virtue of being human. Cultural relativists, on the other hand, argue that values are grounded in specific communities and that the communal group, not the individual, is the basic social unit. However, the ideological spectrum is much more complex; realizing that complexity can help point us to where the challenges to international human rights lie. They are six contemporary ideological challenges to human rights: (1)Radical capitalism: a view held by Western liberals, dismissing social and economic human rights, and confinement of rights to property rights and emphasizing civil and political rights needed to carry out one's own affairs in peace. (2)Communitarianism: Firstly, Traditionalism is adherence to the notion that international human rights conflict with traditional rules for orderly social behavior, and that within the confines of the group, the society protects the human rights of its members. Second, Reactionary Conservatism holds that the "excesses of contemporary freedom," such as women's liberation, LGBTQ rights - in other words "excessive individualism" - are antithetical to social order. Thirdly, Left Collectivism, is a reaction against the West. It holds that national self-determination and relief from Western imperialism and MNCs are the most important human rights. Fourthly, Status Radicalism, is the belief that since rights are systematically denied to certain groups, one's group status and protection of that group's rights are more important than the protection of their individual rights. Finally, Religious Fundamentalism, in its varied forms compel its adherents to believe that human rights are ordained by God alone (Carnegie Council 2003: 2-3). They recognize only the codification of those norms within the religious laws of their so-called holy books and dismiss other public, local, and international law, including international human rights.

- The development of international human rights law generally has been partial and androcentric, privileging a masculine worldview. NGOs have recently begun to document abuse of women that falls within the traditional scope of human rights law. But the very structure of this law has been built on silence of women. The fundamental problem women face worldwide is not discriminatory treatment compared with men, although this is a manifestation of the larger problem (Charlesworth cited in Dixon \& McCorquodale 2003: 180). Women are in an inferior position because they have no real power in either the public or the private worlds, and international human rights law, like most economic, social, cultural and legal constructs, reinforces this powerlessness.

- The human rights approach to the right of self-determination recognizes that the right is a human right but is not an absolute human right. This approach can deal with the changing of values in international society away from the State-based international law towards a more flexible system. Indeed, many of the claims for self-determination arose because the unjust, State-based, international legal order failed to respond to legitimate aspirations of peoples. The limitations on the right of territorial integrity and uti possidetis are both attempts to reassert the exclusivity of the State in international law at the expense of the people of a territory by reasserting the primacy of the State over the rights of people (Hannum cited in Dixon \& McCorquodale 2003: 222). These limitations are at odds with the development of international human rights law and so, under the human rights approach, are given over the right to self-determination only in restricted circumstances.

- The concept of 'international crimes' are generally considered to be offences whose repression compelled some international dimension: genocide, crimes against humanity, war crimes, aggression, piracy, slave trade, trafficking in women and children, traffic in narcotic drugs, hijacking, terrorism and money laundering. Their heinous nature elevates them to a level where they are of 'concern' to the international community. They dictate 
prosecution because humanity is the victim (Schabas cited in Dixon \& McCorquodale 2003: 228). Moreover, humanity is entitled, indeed required, to prosecute them for essentially the same reasons as we now say that humanity as a whole is concerned by violations of human rights that were once considered to lie within the exclusive prerogatives of State sovereignty.

\subsection{Mechanisms: International Human Rights Law}

- States are obligated to respect, protect, and fulfill the fundamental human rights enshrined in the Universal Declaration of Human Rights. As such, they need to ensure access to effective mechanisms and institutions to address grievances and put an end to cycles of discrimination and marginalization. Whether judicial or non-judicial, these mechanisms and institutions must seek to provide redress to victims and ensure accountability for perpetrators of violations. As noted by the Office of the UN High Commissioner for Human Rights (OHCHR), "Justice delivery involves the ability of the State to ensure the peaceful resolution of disputes, the prosecution and punishment of crimes, and effective remedies for violations of rights" (IPI 2017: 4). Solid, independent institutions able to address grievances in a manner that respects human rights reduce the likelihood that individuals or groups will resort to violence when disputes arise. The state must also guarantee equal access to these institutions for all (women, youth, minorities, etc.).

- National human rights institutions can play an important role in promoting and monitoring the implementation of international human rights standards at the national level. These can take different forms, including ombudspersons, human rights commissions, hybrid institutions with multiple mandates, or consultative and advisory bodies. A challenge to human rights in general relates to the lack of enforcement and states' use of the principle of sovereignty to justify their refusal or reluctance to engage on human rights. Human rights tools and mechanisms are treaty-based; they derive from legal commitments voluntarily made by member states in accordance with this principle of sovereignty. However, some human rights, such as the right to life, freedom of conscience and religion, and prohibition of torture, are nonderogable at any time under any circumstances, meaning they are applicable even to states that have not ratified the conventions around them (IPI 2017: 6-7). Yet none of the core human rights treaties provide for solid mechanisms to ensure accountability for their non-fulfillment or violation.

\subsection{Outcomes: Human Dignity, Legality, Legitimacy, Global Justice and Peace}

- International Human Rights Law should have value-oriented approach based on the protection of human dignity proceeding on the premise that demands for human rights are demands for wide sharing in all the values upon which human rights depend and for effective participation in all community value processes. The interdependent values specified are the demands relating to (1) respect, (2) power, (3) enlightenment, (4) wellbeing, (5) health, (6) skill, (7) affection, and (8) rectitude (See McDougal, Lasswell \& Chen 1980 cited in Dixon \& McCorquodale 2003). The ultimate goal is a world community in which a democratic distribution of values is encouraged and promoted; all available resources are utilized to the maximum; and the protection of human dignity is regarded as a paramount outcome of the legal process to redress any human rights violations of an individual/people's. rights.

- Existing monitoring mechanisms within the UN have had little impact. For example, the Human Rights Council's Universal Periodic Review, by which all member states periodically undergo an assessment of their human rights records, basically consists of states reviewing their own track record, with little space given to other stakeholders such as civil society organizations. Despite these challenges, it remains in a state's best interest to uphold the rule of law and human rights. According to IEP's 2017 Global Peace Index, the most peaceful countries are those with the most solid human rights records (See IPI 2017: 7). While this is not to suggest a simple or linear relationship between upholding 
human rights and peace, the data indicates that violating or failing to uphold human rights does not sustain justice and peace or make societies just and peaceful.

- Constructivists argue that there is no necessary tension between the interests of sovereign states and the moral principles associated with the promotion and protection of human rights. the important theoretical point here concerns the constitutive nature of international political reality, specifically how states create - and are created by - shared norms and values. The development of human rights needs to be understood according to this dynamic. As is often the case in social life, the international realm is made up of many contending sets of expectations and rules as to how actors ought to behave. While the historically dominant realist logic suggests one form of international conduct, constructivists argue that this inter-state order has been transformed by the emergence of universal values. The protection of human rights therefore becomes 'integral to the moral purpose of the modern state, to the dominant rationale that licenses the organization of power and authority into territorially defined sovereign states. Constructivists argue that if states reject universal values outright, they will have to pay a price: this could take the form of condemnation, exclusion, or possibly coercive measures aimed at forcing the new standard of legitimate statehood (Dunne \& Hanson cited in Dunne \& Wheeler 1999: 64). Hence, Constructivists argue that, in practice, human rights should not be regarded in opposition to state sovereignty but rather as an emergent standard for legitimate statehood.

- Connecting the human rights and sustaining justice and peace agendas offers a unique, strategic entry point to help shift from a culture of crisis management to one of prevention, especially in a global context where human rights tend to be restricted or attacked in the name of security. The UN's Human Rights Up Front Initiative, which requires the entire "UN system to be alert to deteriorating human rights situations," is a step in the right direction and should be strengthened across all UN pillars. Furthermore, human rights are universal, indivisible, interdependent, and interrelated, meaning they are rules that can be referred to and claimed by any individual (regardless of his or her nationality) at any time (IPI 2017: 7). The legitimacy of human rights because of their universality makes them a solid foundation for building and fostering self-sustaining peace. This is further demonstrated through the strong and positive correlation found by IEP between the "acceptance of the rights of others" and states' levels of justice and peacefulness.

\section{Discussion}

The Global Human Rights Regime, an amalgamation of law, permanent institutions, permanent institutions, global campaigns, and funding, is a remarkable achievement. Since the mid-1980s and particularly after the Cold War, human rights have been embedded in numerous conventions, organizations, and courts, at the domestic, regional, and international levels, all of which now encircle states in a world of law. These institutional achievements are mirrored in global surveys that show most of the public in countries worldwide support the idea of human rights (Hopgood 2014). Hence, the liberatory potential of human rights is a significant development in the developments in the law and compliance regime of human rights.

The notion of the individual in the global context is a concept broader than citizenship with protections of individuals based on their personhood, not their citizenship. Significantly, all states, not just the state of nationality, owe all peoples, not just their citizens, these international protections. The modern view of human rights, placing the individual at the center, emerged in 1945 in the wake of the Nuremberg and Tokyo trials and vivid awareness of the Nazi human rights atrocities. Hence, the lesson from Nuremberg and its progeny is that state sovereignty cedes to human rights protections. The UN secretarygeneral Boutros Boutros Ghali in 1992 “... announced a new era where human rights would increasingly impose conditions on legitimate sovereignty. The time of absolute and exclusive sovereignty has passed" (United Nations 1992 cited in Hopgood 2014). 
Consequently, international human rights norms set the proper baseline scope and limits of state intervention in civil society as well as the threshold observance of such rights in any regional or international agreement.

There are, nevertheless, a series of concerns about the present and future of human rights effectiveness shared by scholars and advocates alike. One set of questions concerns the impact ideological framework on current effectiveness. While these questions are not new, they are growing greatly in significance because of deeper underlying shifts in the world of global politics. It is here that we find the real cause of the growing ineffectiveness of human rights as an instrument for restoring human dignity in case of violations. They are the decline of Western liberal influence and the emergence (or re-emergence) of new powers namely China, Russia, Egypt etc. the politicization of human rights language, and pushback against human rights on principle, particularly in cases of religious belief (Hopgood 2014: 69). All these put intense pressure on the idea of international human rights and its legality protected by International human rights law.

For the first time in more than two decades, human rights are being openly rejected in the name of the fundamental organizing principle of world politics: sovereignty. China and Russia in particular leads the way in direct attacks on human rights organizations and ideas in principle, followed by states as diverse as Sri Lanka, Cambodia, Uganda, and Uzbekistan. Saudi Arabia, one of the world's most systematic human rights abusers, even rejected its Security Council seat using the language of rights while ASEAN's human rights declaration accepts as legitimate constraints on human rights stating: "... national security, public order, public health, public safety, public morality, as well as the general welfare of the peoples in a democratic society" (ASEAN 2012 art. 8 cited in Hopgood 2014: 71). All of which makes a mockery of the legal protections that individual rights are supposed to provide. In other words, human rights language will be ac acceptable where it is diluted of all significance and resisted or ignored where it still carries weight. In a Chinese American world, the language of international norms will need to be transformed into one more tolerable to Beijing than that of human rights. This is not capitulation; it is political reality harming the cause of global justice and peace.

The Global Human Rights Regime aspirations build on global justice and peace is greatly challenged by all major religions. Why does religion matter so much? Because universal human rights are constitutively secular: they have as their starting point the moral equality of all human beings regardless of any aspect of their identity. Nothing could be more foundational to the idea of human rights. Religions are not like this. They legitimate themselves according to transcendental or spiritual principles, not human legal constructions, they distinguish between believers and non-believers, they have strong and deeply held views about the sanctity of life, legitimate violence, appropriate social structure and conduct, and they command billions of followers of greater or lesser intensity. Even if religious leaders selectively engage in certain contexts with the demand for specific rights, like against torture or poverty, they are not building the power-base nor the normative foundations of global human rights (Hopgood 2014: 72). They constitute a standing challenge to secular moral and legal authority unless they recognize the superiority of human-made law.

\section{Conclusion}

In this paper basing on Waldron, we argued that dignity is born as a juridical idea, as a status, tied up with rank, conferred to some individuals only, in virtue of their offices. He points out that, in modern time, starting from Kant, the concept has changed its nature: it turns into a moral idea, conceived as an intrinsic worth, recognized to every single human being, in virtue of their humanity. According to Waldron the thesis that human dignity is an intrinsic worth is wrong: the concept of human dignity has a legal recognition and no need of an underlying moral dignity is required. Placed as ground of human rights, the term "dignity" has changed in extension, but not in intension: it still denotes a status, assigned 
no longer to some individuals only but to everyone. It expresses the idea of a high-ranking status, comparable to a rank of nobility - assigned now equally to every person (Waldron cited in Malvestiti n.d.). We argue that a necessary condition to grant human dignity an existence as a ground of rights is to consider it not only as a status, but also as a value.

The context for considering the human rights movement's dynamism is the development of intercultural, indeed global dialogues about the meaning, interpretation, and refinement of human rights and practical strategies for their implementation in the contemporary world. These dialogues include those that are internationally sponsored, government sponsored, and NGO sponsored (including in the latter educational institutions and associations). These dialogues have given rise to much talk of overlapping cross-cultural consensus about human rights standards as well as practical strategies for instantiating a human rights ethos in the communities and institutions of the world. A case in point is the 2007 Chicago Principles on Post-Conflict Justice (Chicago Principles 2007), a joint project spear-headed by international NGOs on human rights, global affairs, criminal science, and penal law, assisted by a vast consultation with justice officials, law faculty, and NGOs from countries in North America, Latin America (Central and South), Europe (North, Central, and Eastern), and Africa (North and sub-Saharan) (Twiss 2011: 218). These principles attempt to integrate criminal, compensatory, and restorative justice for post-conflict societies in a unique manner-by recommending the combination of reconciliation, prosecution, reparation, reconstruction, memorialization, education, and the advancement of healing and solidarity-all based on fundamental human rights norms, both civil-political and socioeconomic.

In the end, applying the new evaluative framework made a big difference: we attempted to position international human rights law in its proper place as nothing less than the foundation of human civilization. We evaluated older, established norms of international human rights law, such as sovereignty, but also new, emerging, and more divisive norms, such as economic globalization. When evaluating any of the norms, the criteria was the same: is the norm likely to advance global peace and justice, and is the norm interfering with basic human rights? Global Human Rights Regime is not necessarily something that would grow out of most existing theories of global justice and peace, but it is a norm that evolves with practice and must be seen, at least for now, as an important tool of international human rights law. Our emphasis in this paper was to use human rights paradigm focused on eliminating violations and abuses and its importance as a norm to build global justice and peace. The answered questions are a clear sign that we must do the hard work to adopt the vocabulary of global justice and peace to the reality of international human rights law.

\section{Reference:}

- Carnegie, Council. (2003) The Challenge to International Human Rights. https://www.carnegiecouncil.org/publications/articles_papers_reports/905

- Dixon, M. \& McCorquodale (2003) Cases \& Materials on International Law (4th Ed.). Oxford: Oxford University Press.

- Donnelly, J. (2003) Universal Human Rights in Theory and Practice (2nd Ed.). Ithaca, NY: Cornell University Press.

- Dunne, T. \& Wheeler, N.J. (Eds.) (1999) Human Rights in Global Politics. Cambridge: Cambridge University Press.

- Freeman, M. (2002) Human Rights: A Multidisciplinary Approach. Cambridge: Polity Press.

- Hernandez-Truyol, B. E. (1997) Civil and Political Rights: An Introduction. University of Miami Inter-American Law Review (223).

- Hopgood, S. (2014) Challenges to the Global Human Rights Regime: Are Human Rights still an Effective Language for Social Change? SUR - International Journal on Human Rights, (11) 20, Jun/Dec. 
- International Peace Institute. (2017) Human Rights and Sustaining Peace. New York: International Peace Institute.

- Malvestiti, B. (n.d.) Human dignity as a status vs. human dignity as a value. A Double Nature. Milan: University of Milan.

- Pawson, R. \& Tilly, N. (1997) Realistic Evaluation. London: Sage.

- Sohn, L.B. \& Buergenthal, T. (1973) International Protection of Human Rights. Oxford: Oxford University Press.

- Twiss, S. B. (2011) Global Ethics and Human Rights: A Reflection, The Journal of Religious Ethics, (39), 2, June 2011, pp. 204-222.

\section{Abstract}

Aim: This article addresses the relationship between International Human Rights Law and humanity's struggle for global justice and peace. Many of the problems we encounter especially human rights abuses - are the gravest threat to humanity's aspirations for global justice and peace. To realize just societies that show suitable solidarity with fellow human beings and strive for peaceful and fair global relationships, under the shadow of human rights abuses constitutes one of the main challenges of our age. The phrase "human rights" may be used in an abstract and philosophical sense, either as denoting a special category of moral claim that all humans may invoke or, more pragmatically, as the manifestation of these claims in positive law, for example, as constitutional guarantees to hold Governments accountable under national legal processes. While the first understanding of the phrase may be referred to as "human rights", the second is described herein as "human rights law" In this paper we try to better understand the world around us in the context of how juridification of international human rights law is exemplified by the unequivocal acceptance that all rights are justiciable.

Methodology: Realistic Analysis method was used for this study by recognizing the importance of understanding how contextual factors influence human rights law. A form of theory-driven analysis, realist analysis acknowledge that interventions and their outcomes are subject to contextual influence. As such, a realist analyst's duty is to understand "how, why, for whom, and under which conditions" interventions work. To do so, the contextmechanism-outcome configuration $(\mathrm{CMOC})$ is central to analysis for realist studies. CMOCs describe how specific contextual factors (C) work to trigger mechanisms (M), and how this combination generates various outcomes $(\mathrm{O})$. By exploring these mechanisms of change, realist evaluations aim to understand how a law works or is expected to work within specific contexts, and what conditions may hinder or promote successful outcomes. Realist analysis therefore seek to explain generative causation within the social world by identifying patterns of interactions.

Outcomes: Most importantly, International Human Rights Law by giving judicial inscription gives legality to human rights. It brings pressure on people at large to agree with these positivized human rights and support them hence give legitimacy to human rights. The Law since 1948 has developed a new benchmark of legal imagination: human dignity. The tension between legality, legitimacy and human dignity contains one of the many challenges of democracy making the realization of global justice and peace look utopian in character. Hence, it is recommended that all the countries should enact "human rights law" making it integral to the legal system and superior to ordinary law and executive action to realize humanity's collective aspirations for global justice and peace.

Keywords: International Human Rights Law, human dignity, Legality, Legitimacy, Global Justice, Global Peace 